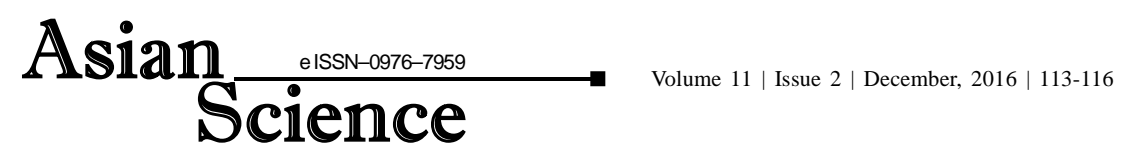

DOI : 10.15740/HAS/AS/11.2/113-116

Visit us | www.researchjournal.co.in

RESEARCH PAPER

\title{
Knowledge and adoption of recommended cultivation technologies by the chilli growers
}

\author{
S. S. PINGALE, A. N. DESHMUKH*, S. U. MOKHALE AND G. T. ZORE \\ Department of Extension Education, Shri Shivaji Agriculture College, AMRAVATI (M.S.) INDIA
}

\begin{abstract}
The present study on "knowledge and adoption of recommended cultivation technologies by the chilli growers" was conducted in the year 2015-16 in Amravati district. For this study 60 chilli growers were purposively selected from one tehsils of district with the help of random sampling method. The data were collected with the help of structured interview schedule. Collected data was carefully examined, classified quantified and tabulated. Frequencies, mean, standard deviation, correlation of co-efficient analysis were employed for interpreting the results. Results obtained after analysis have been summarized as below. Findings revealed that majority of the respondents 75 per cent were find in the medium experience in chilli cultivation group. Majority of the respondents 61.67 per cent were educated upto college level. Nearly the respondents 50 per cent belonged to semi medium land holding between 2.01 to 4 ha. Maximum percentages of the respondents had their annual income in between Rs. 50,001 to 1,00,000/- and above. Majority of the respondents 70 per cent were had low area under chilli. 70 per cent of the respondents had medium labour availability. 63.33 per cent respondents had area under irrigation upto 2 ha. 40 per cent of the respondents had medium extension contact. 55 per cent of the respondents had medium source of information. Majority of the respondents had medium risk orientation. 68.33 per cent of the respondents had medium level of market orientation. 56.66 per cent of the respondents had medium level knowledge, whereas 68.33 per cent of the respondents had medium level adoption. Findings of relational analysis revealed that the characteristics such experience in chilli cultivation was negatively and significantly correlated while education, land holding, annual income, area under irrigation, labour availability, area under chilli crop, extension contact, source of information and risk orientation were positively and significantly correlated with knowledge about recommended practices of chilli. Whereas market orientation were not associated with knowledge about recommended practices of chilli. Among the characteristics of respondents viz., land holding, education, annual income, area under chilli crop, labour availability, area under irrigation, source of information and risk orientation were positively and significantly correlated with adoption. Whereas experience in chilli cultivation, extension contact and market orientation were non-significant with adoption. Market fluctuation, high cost of insecticides and pesticides, high cost of fertilizer, irregular power supply, high wages of labour were the important constraint.
\end{abstract}

Key Words : Knowledge, Adoption, Chilli growers, Practices, Constraints

View point paper : Pingale, S.S., Deshmukh, A.N., Mokhale, S.U. and Zore, G.T. (2016). Knowledge and adoption of recommended cultivation technologies by the chilli growers. Asian Sci., 11 (2): 113-116, DOI : 10.15740/HAS/AS/11.2/113-116.

\footnotetext{
* Author for correspondence
}

A. N. Deshmukh, Department of Extension Education, Shri Shivaji Agriculture, College, AMRAVATI (M.S.) INDIA 